\begin{tabular}{|c|c|}
\hline \multirow{3}{*}{ 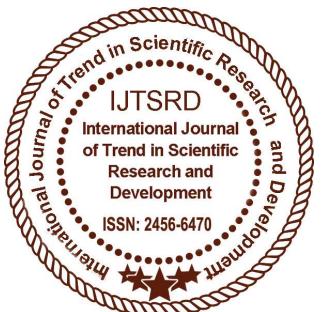 } & $\begin{array}{l}\text { International Journal of Trend in Scientific } \\
\text { Research and Development (IJTSRD) }\end{array}$ \\
\hline & International Open Access Journal \\
\hline & ISSN No: 2456 - 6470 | www.ijtsrd.com | Volume - 2 | Issue -4 \\
\hline
\end{tabular}

\title{
Impact of In-room Facilities on Repeat Business in Hotels in certain cities of Maharashtra (with reference to 3, 4, 5, and 5 star deluxe hotels in Mumbai, Pune, Nagpur)
}

\author{
Dr. Rasika R. Gumaste \\ Assistant Professor, AISSMS's College of \\ HMCT, Pune, Maharashtra, India
}

\author{
Dr. Shefali Joshi \\ In charge Principal, Suryadutta CHM \& TT, \\ Pune, Maharashtra, India
}

\section{ABSTRACT}

The hotel business is highly competitive, especially as today the supply of rooms exceeds the demand in the market. The guest rooms are the main revenue earning product of the hotel. The hotels provide a range of facilities to suit the tastes and pockets of the customer. The hotels retain their customers by offering different themes, contemporary designs and some offer unique facilities and services. Hotels that can attract, maintain, satisfy and retain customers are more likely to survive in the competitive market and will earn good revenue, higher occupancy percentage and better revenue per available room for the hotels. Cleanliness and hygiene was rated as the most important factor by the Hoteliers as well as the Customers for a guest to return to a hotel.

\section{Keywords:}

1. Amenities- The term amenity is commonly used to identify luxury items that a hotel gives away to its guests at no extra charge, although the cost of those items is often hidden in the room rate.

2. Business trip -defined as all non-discretionary trips which occur either explicitly for the purpose of engaging in the work, or incidentally in the course of conducting work related activities.

3. Customer satisfaction-Customer satisfaction is a marketing term that measures how products or services supplied by a company meet or surpass a customer's expectation.
4. Facilities -All items that are provided in the hotels which are conducive to the guest's increased material comfort and convenience, it is a broader provision compared to amenities.

\section{INTRODUCTION}

A hotel survives on the sale of rooms; it constitutes almost $50 \%$ of the total sales of a hotel. Thus the major part of the hotel's margin of profit comes from the room sales. The hotel attributes and services are considered as the important determinants for the customer satisfaction. The hotels retain their customers through the strength of their loyalty programmes, others 'wow' the guests by their unique themes and contemporary designs, and some offer unique amenities and services to their customers. Guests' expectations of hotel amenities and facilities are affected by the type of the hotel and its sophistication level. It is important to fulfill the expectations of a guest when he pays to stay in a room. While the guest pays a fixed tariff, a lot of perks and privileges are offered in for 'free' with the hope that it would influence the customers to patronize the hotel again. The ability of a hotel to attract and retain customers is important for good revenue generation, higher occupancy percentage and better revenue per available room for the hotels.

The hotels depend largely on the business customer for the major share of their business. MICE (Meetings, Incentives, Conferences, Exhibitions) segment is one of the fastest growing segments within 
the Indian Tourism Industry and contributes to a large extend towards the hotel business. India has developed a reputation as a unique MICE destination, with its historical, cultural, architectural, wildlife, culinary, spiritual and therapeutic attractions. (Asia Pacific, Business and Technology Report, 2012). The business guests are a critical market to the hoteliers as they boost occupancy levels, especially during low seasons and weekdays.An understanding of the accommodation attributes that the business traveller perceives is of substantial interest to the hoteliers that target this market sector. As the demand for rooms required by the business customers may be immediate depending on the work, there is a scope for flexible earnings for the hotel.

The corporate accounts are the main source of business for the hotels. With proper management of corporate accounts the hotel can earn good revenue rather than trying to build direct relationships with each and every business customer. The frequency of business customer is much more compared to the leisure customer, even though the span is shorter. The business customer requires more service amenities, special equipment and attention from the hotel to ensure they did not lag behind in this time-is-money era. The business hotels provide the best conferencing venues, technology, cuisines, well trained service team and customize the services as per the clientele need. The business tourist may to be accompanied by family members and avail leisure facilities. Hotel companies which have a wide-range of brands within their portfolio must distinctly position each one of them in the eyes of the consumer in order to maximize market share. The hotel brands are differentiated based on the attributes like the degree of luxury and comfort of the physical amenities, the ambience and location of the hotel, meeting rooms, business center, restaurants, swimming pool and exercise facilities, quietness, safety, cleanliness and special rewards programs for frequent guests. The quality and range of services offered by hotel, the scheduling and speed of service, the caliber of the service personnel is the key criterion in differentiating the hotel brand.

The hotels can store huge amounts of information on the customer's preferences through the Guest Satisfaction Tracking System (GSTS) which are very useful each time the customer goes back to the same property or to the other properties of the same chain. They help the marketing department plan frequentstay programs, special discounts, make managers understand the needs of the customers leading to guest satisfaction.

The hotel amenities and services are upgraded as per the profile of the guest. The hotels have a guest recognition programme for the repeat guest.The hotel carries out a market research in order to discover new markets, investigate the profile of customers in terms of their needs and wants, and obtain the required information to develop new products. The knowledge about effects of services for existing and potential customers on loyalty is a part of effective marketing. The programme allows the guest to tailor their stay to meet the individual needs and preferences. The member benefits and upgrading the rooms for regular customers include a dedicated check-in area, rooms on the higher floors, better view, corner rooms, special amenities, rooms on club or executive floors as identified by the brand of the hotel, late checkout, early check in, option to hold the room for certain hours during departure, 24 or 48 hours reservation guarantee. The repeat guests are categorized as VIP 3 . The classification of hotel properties has been introduced in the industry worldwide to provide clues to the customer to select a property that meets their requirement. Although the five-star and four-star hotels in India have been able to meet international standards, some of them do not figure on the global map.The hotel selection factors identified for the study include cleanliness in the hotel rooms, services and amenities provided, customized services, quiet environment, décor, ecological aspect, updated technology, and various themes.

Mumbai, Pune and Nagpur were selected for the research as these cities have maximum number of star hotels in Maharashtra. Mumbai is the financial capital of India. The business customer needs business facilities and services, and is looking for a sophisticated experience. Most of the domestic as well as international hotel chains have their flagship hotels in the city. There has been tremendous growth in the number of hotels every year which includes all categories of hotels from the 3 star to the 5 star deluxe hotels.

The city of Pune has seen a tremendous growth in various sectors like medical tourism, information technology, automobile manufacturing, education and the hospitality industry. There are many 5 star and 5 star deluxe hotels, with a total room inventory of more than 5000 which includes hotels of all categories and the lodging industry as well. 
Nagpur, popularly known as Orange city, the second capital of Maharashtra, is a developing city situated strategically at the center of India. There is a development of many new business, economical projects like (MIHAN) Multi-modal International Cargo Hub and Airport at Nagpur. The aim of the project is to make use of the central location of Nagpur and convert the present airport into a major cargo hub with integrated road and rail connectivity. The city has few star category hotels compared to Pune and Mumbai, but many hotel chains are intending to come here due to the growth of industries.

\section{OBJECTIVES}

1. To study the attributes of In-Room Facilities in different categories of Business Hotels.

2. To analyze the impact of In-Room Facilities on Customer Satisfaction leading to Repeat Business in hotels.

\section{PURPOSE OF STUDY}

- Guestrooms in the hotel are like "Cash Cows". Not only do such additional hotel amenities attract new guests but they also increase the occupancy rates and revenue earning for the hotel.

- Hotels of different categories provide a high level of Guest Services and Hotel Facilities to attract and sustain guests. Understanding the features that are perceived to be important by the customer for the choice of hotel helps the management to make optimal hotel development decisions and emphasize on those attributes.

- The function of Facilities is to give a competitive advantage. It can be a differentiator for a hotel and establish its brand value and reputation in the market. It is imperative for any hotel company to set high benchmarks in housekeeping if it wants to attract new guests and repeat clientele

- Facilities and Services in the guest room are important for the satisfaction of the guest leading to the repeat customer.

\section{Literature Review-}

Many studies have been carried out over the years to understand the needs of the business traveller. The hotel guest room attributes change over a period of five to ten years and hence the studies included for literature review are mostly within ten years and some important studies done in the previous years are covered. Different brands provide the facilities for the business traveller under different heads. For example Marriott hotels provide the business facilities as the "Room That Works" whereas the Hilton has "The Smart Desk. The Starwood Property, Westin has the "Guest Office" and "Room 2000," for the business traveller, whereas Hyatt has "The Business Plan" for the customers. Multiple studies from the literature review have suggested that business travellers do need internet access while they travel. All luxury hotels provide free internet services whereas few of the budget hotels provide such free services. Technologically advanced facilities are the most important for a business guest in the hotel.

A thesis by Clare Jay (2011) tries to seek the reasons for hotel's choice of amenities and to what extent a hotel's amenity selection provides the hotel with a competitive advantage. This research also seeks to understand the effects that provision of guest amenities and facilities have on hotel front office and housekeeping staff. A study by Fazuin Mohd. Yusoff (2011) identified hotel selection attributes for Middle East Customers as location, services, cleanliness and facilities. The guest staying at the three star hotels expected basic facilities like the television and a good toilet, where as the ones in five star expected larger size rooms, pleasant atmosphere, more comfort in general and internet facility. "Reputation or brand image," "Cleanliness," "Complimentary Parking," "Room Rate" and "Convenient Front Desk System" rank high in importance in the survey done by Philips (2011) regarding 13 attributes in a business hotel and budget hotel. It also examined how well the hotels satisfy consumer expectations related to these attributes along with the guests' satisfaction level related to the revisit intentions.

There are many in- room attributes which lead to a guest coming back to a particular hotel. One of the most important factors is cleanliness. The paper by Nelson Barber (2010) examines the dimension of cleanliness in detail through the creation of a measurement scale and considers customers' perceptions and willingness to return. A study done in Cairo related to business hotels revealed that business guests at the five-star hotel rated "cleanliness of room," as the second important attribute followed by "comfortable mattress and pillow "as next. The Business travellers at the four-star hotel in the same study rated "security and safety of room" as the most 
important factor followed by "quality of bathroom facilities," "cleanliness of room," as the third most important factor (Ahmed Fawzy, 2010).

Also a study by Alfred Ogle, (2009) examines the guest rooms as the important determinant of guest stay satisfaction. The results suggest that a holistic approach which includes all the human senses in the room designing is required to optimise the guest's overall experience related to rooms and act as a marketing tool for the hotel. Among the human senses 'sight' was what hoteliers considered the dominant sense for the guests, followed closely by the sense of 'smell' concerning the guest rooms.

The study by Sara Dolnicar, 2002, has tried to assess the expectations or the dissatisfaction perspective of the business travellers staying in various categories of hotels. "Hygiene and cleanliness" was rated as the leading one, as the one expected by the guest in the room and also a dissatisfied. Out of the many studies carried out in the previous years, some important ones are by Chu \& Choi (2000), the findings of which show that guest rooms, front desk activities and security were considered as the top priority by the business guest while selecting a hotel in the city of Hongkong.Another study by Tat Y. Choi (2000) assesses what is important for Asian and Western travelers. It suggests that the satisfaction of the Asians travelers is related to the value factor while quality of room is important for Western travelers.

Generation Y customers will expect free Wi-Fi access, hotel rooms that can hook up to and be controlled by their mobile devices, areas within the hotel to socialize in, personalized experiences that give them choices over every possible option the hotel can offer, and the newest technology available for them to use (Kelley,2012).

.A paper by Zainal Abiddin Kassim, (2010) analyses the impact of providing complimentary in -room internet access to the business traveller. It suggests that by providing it hotels can help influence a business traveller's hotel selection, increase their satisfaction and loyalty towards the hotel and brand which ultimately will improve the hotel's financial performance.

A study by Eric Chan(2004) states that "adequate jacks and plugs," "satellite/cable TV," and "high speed Internet access" were ranked by business travellers as the top three in-room Information Technology facilities. However the hoteliers agreed that it was difficult to provide updated facilities all the time due to the fast changing technology. The Management wants to ensure that with the right technologies and equipment, they create a truly memorable experience for their guests. The hotels have focused on employing and embracing modern information technology as a means to improve employee productivity, enhance revenue and gain customer loyalty (Lee, Barker, Kandampully, 2003).

The expectations of the guest from the five star deluxe hotels are different from those of a budget hotel. The guest expects luxury and customised services when he stays in such a hotel, also the perception of luxury may differ from one guest to another.Another very important factor which attracts the customer and acts as a major marketing tool is the "green hotels" and sustainable products to save the environment. Thus the eco certification has become important and mandatory for the hospitality industry. Wouter Geerts (2014) has argued that the business travellers are not willing to put in extra effort into carrying out environment related practices while staying in hotels. Business travellers are often sent to unfamiliar locations, and are expected to take on a high workload when at the destination. By comparing the uptake of environment related practices at home and when away, it is argued that the strain of travelling negatively impacts the uptake of these practices. The results of a survey carried out by Anuraag Jhawar, 2012 illustrate the lack of consumer knowledge regarding eco-certification programs for the hotels, especially in terms of what they are and how they function. The research by Millar, 2008 says that one of the most influential factors for choosing hotel for the guest is its green hotel certification. There was a slight difference between the choice of facilities for the business and leisure travelers on points like the preference for green hotel and some ecofriendly amenities.

\section{Limitations of the study-}

1. The respondents in this study included will be limited to certain cities of Maharashtra which would include Nagpur, Pune and Mumbai.

2. The study shall be limited to Five star deluxe, Five star, Four star and Three star hotels of the above mentioned cities only.

3. The study only focuses on measuring Customer Satisfaction related to guest room attributes. There 
could be other reasons for a customer to select a hotel for his stay, which can be studied.

4. Most of the hoteliers are very busy in operations and cannot find time to fill up questionnaires and a constant follow up is required

5. Less number of hotels in Nagpur city.

6. To overcome these difficulties and to complete the study, sincere and timely efforts have been put.

\section{Research Methodology}

- The subjects of the study were hoteliers and business customerswho stayed over at least one night in the business hotels in the selected cities of Maharashtra.The tool used for sampling was questionnire. The questionnaires were filled by the top management, middle management and supervisors working in Housekeeping and Front Office department of different categories of hotels.

- The hotels considered for the research are approved hotels under various teategories according to Ministry of Tourism, Government of India, HRACC listing.

\section{RESULTS AND DISCUSSION}

\section{Responses of Hoteliers related to Hotel Room Facilities}

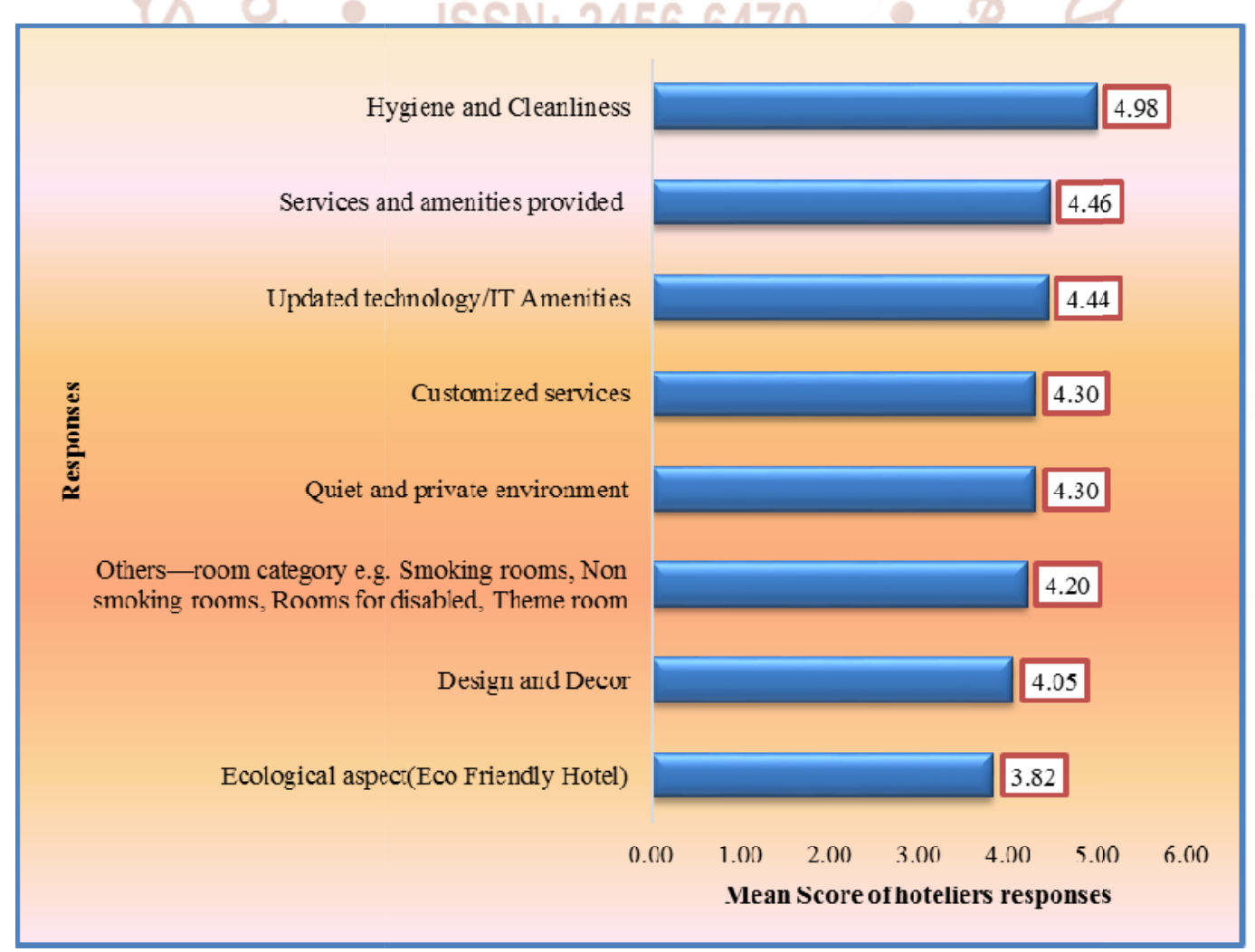


In the mean score analysis of Hoteliers responses related to the choice of hotel room , Hygiene and Cleanliness is rated as the most important factor by the hoteliers, followed by Services and amenities provided, Updated technology or Information Technology amenities, Customized services, Quiet and private environment. The factors like the other room categories eg.smoking rooms, non-smoking rooms, rooms for disabled, Theme rooms and Design and decor rank $6^{\text {th }}$ and $7^{\text {th }}$ respectively. The Ecology factor ranks last in the mean score rating of the factors influencing the choice of room in the hotel.

\section{$\underline{\text { Responses of Customers related to Hotel Room facilities }}$}

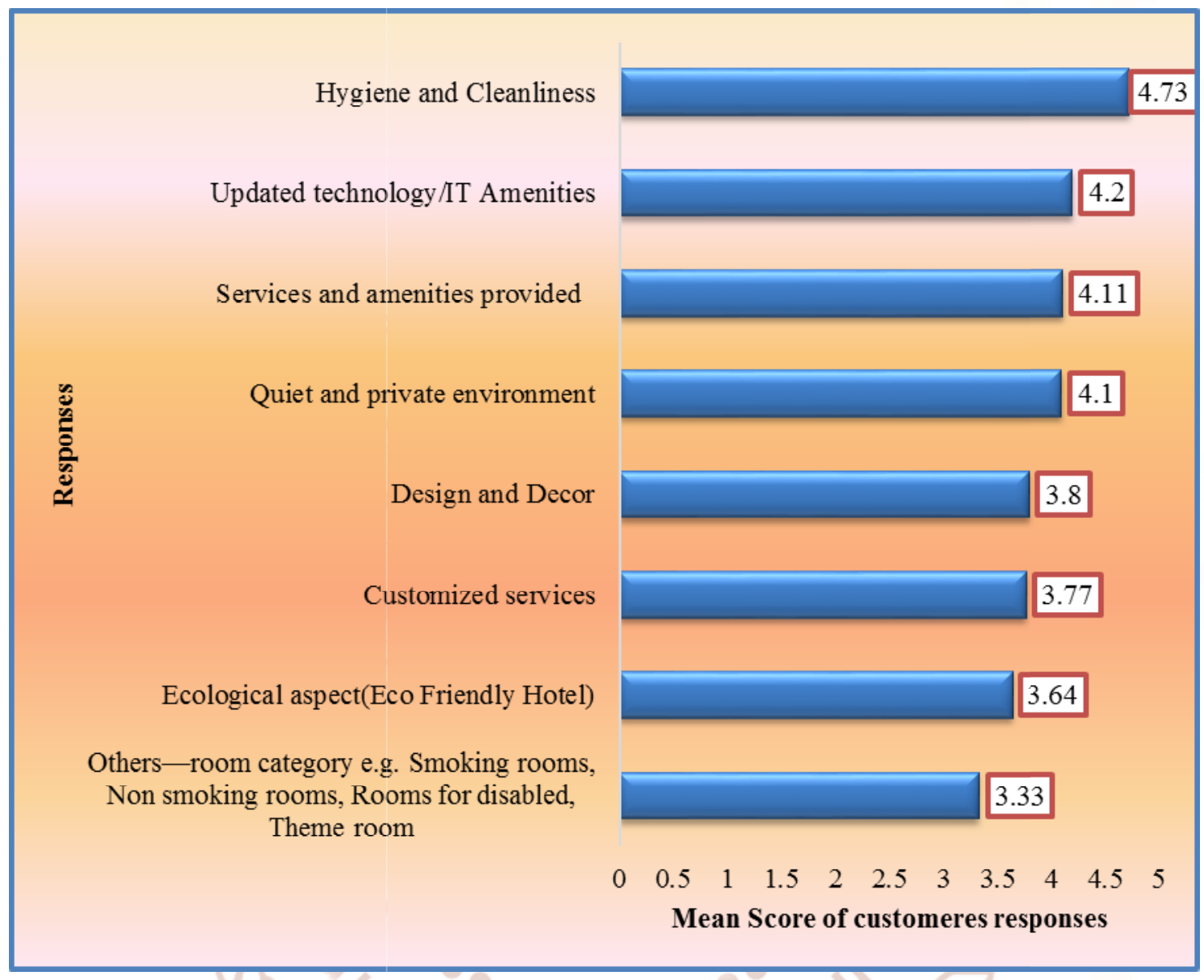

In the mean score analysis of customers responses related to the choice of hotel room, Cleanliness is rated as the most important factor by the customers, followed by Updated technology or IT amenities, Services and amenities provided, Quiet and private environment and design and décor as the first five important factors. The factors like customized services, ecological aspect of hotel, and the other room category are rated low by the customers.

\section{CONCLUSIONS}

- In the research analysis of the hotelier's responses as well as Customer's, the guestrooms were rated as the most important product for the hotel. The hotel uses amenities and in-room Facilities to improve the brand in the competitive market.
- In the research analysis of hotelier's responses towards factors influencing the choice of hotel guest room, Hygiene and Cleanliness was rated as the most important factor.It was found that Hoteliers and Customers have same line of thinking related to the room factors. Hygiene and cleanliness was ranked first by both the hoteliers and the customers.As per the review of literature, Cleanliness is a recurring factor in the determination of guest satisfaction with the guestroom, its quality being highly ambiguous and subjective depending on an individual's perception. Yet, it is the most frequently mentioned attribute that hotel guests use to evaluate a hotel critically. Irrespective of segment, the hoteliers considered Hygiene and Cleanliness of rooms as one of the important factors when either selecting a hotel for the first time or for 
repeat visit. Lack of Cleanliness might be the prime reason for a guest not to select a particular hotel.

- Updated technology was rated higher by the Customers compared to the Hoteliers. The hoteliers need to update technology to keep its guest satisfied. Services and amenities are rated third by the Customers compared to the Hoteliers. These attributes are less important compared to hygiene and cleanliness and Updated technology to the customer.

- During the ranking of the factors for influencing the choice of hotel room by the Hoteliers and Customers, for Three star and Four star category of hotels ,the Customers expect better decor, updated technology, quiet and private environment and ecofriendly hotels .

- During the ranking of the factors for influencing the choice of hotel room by the Hoteliers and Customers, for Five star category of hotels, the customers expect better decor, quiet and private environment and a choice for various Themed and special category of rooms than what was offered.

- During the ranking of the factors for influencing the choice of hotel room by the Hoteliers and Customers, for Five star deluxe category of hotels ,the customers expect better updated technology, decor, services and amenities, and ecological sensitivity.

- It can be concluded that if the expectations of the Customers are met they would be satisfied by the Facilities of the hotel and would return back adding to the revenue of the hotel and survival in the competitive global market.

- Thus from the perspective of expectations it becomes clear that the group of business customers is very heterogeneous and that members of this segment not only make use of different hotel categories but also express differing expectations concerning their accommodation in different category of hotels.

\section{SUGGESTIONS AND RECOMMENDATIONS}

After conducting this research and getting insight from the relevant research, the researcher would like to recommend the following-
1. Added research on the same concept can be carried out on other type of hotels than just business hotels. It may yield interesting insights related to the role that in-room facilities play in getting a repeat customer.

2. Customization of services related to the guests in the hotel needs to be further investigated as it is the key strategy to improve hotel guest experience. The staff should know more about their guests so they can deliver personalized experiences that create valuable relationships and lifelong customers. Using guest data, hotels can better understand and engage their customers increasing loyalty and revenue. It helps the hotel to differentiate in the competitive hospitality environment.

3. Furthur research can be done on the sustainability aspect in the hospitality sector in India. Very few hotels actually practice the ecological aspect inspite of using maximum resources to run the hotel. The mandatory regulations are carried out only for certification and not in actual practice. If the eco aspects are carried out properly it will be beneficial for the hotel as well as the society.

4. The replicated study should be continually conducted and more varieties of amenities should be tested. Since technology develops so fast, there will always new technologies available, which can help business customer to be more productive. It is important to hotel managers to keep their facilities updated and in line with technological advances, not in behind of their guest's technological needs.

5. The hotels should take and act on the feedbacks by the customers. While improving the inconsistencies it is important to distribute guest feedback to the people who are actually interacting with those guests rather than just hoarding it in a market research-type function and just making related reports.

\section{BIBLIOGRAPHY}

1. Ahmed Fawzy, (2010). Business Travelers' Accommodation Selection:A Comparative Study of Two International Hotels in Cairo, International Journal of Hospitality \& Tourism Administration, 11:138-156, ISSN: 1525-6480 
2. Alfred Ogle, (2009).Making sense of the hotel guestroom, Journal of Retail \& Leisure Property, 8, 159-172.

3. Andrea, (2010). London hotel toiletries: what should you get? London Hotels Insight. Retrieved from: http://londonhotelsinsight.com

4. Anuraag Jhawar, GuneetKohli, Jie Li, NeilufarModiri, Veronica Mota, Ryan Nagy, Heiley Poon and Clifford Shum,(2012). EcoCertification Programs for Hotels in California: Determining Consumer Preferences for Green Hotels, Environmental Science Senior Practicum, Spring 2012.

5. AzizanMarzuki, Tan Lay Chin and Arman Abdul Razak, (2012). What Women Want: Hotel Characteristics Preferences of Women Travelers, University Sains Malaysia Malaysia,www.intechopen.com

6. Barber, N., Goodman, R.J. \& Goh, B.K., (2011). Restaurant Consumers Repeat Patronage: A Service Quality Concern, International Journal of Hospitality Management, 30(2), 329-336.

7. Bendall-Lyon, D. \& Powers, T. L. (2002). The impact of gender differences on change in satisfaction over time, The Journal of Consumer Marketing, 19 (1), 12-23.

8. Brownell, J., (2011). Creating value for women business travelers: Focusing on emotional outcomes, Cornell Hospitality Reports, 11(12), 617.

9. Choi, T.Y. \& Chu, R.(2001). Determinants of Hotel Guests' Satisfaction and Repeat Patronage in the Hong Kong Hotel Industry, International Journal of Hospitality Management, 20, 277-297.

10. CihanCobanoglu, Katarina Berezina, Michael L. Kasavana, Mehmet Erdem, (2010). The Impact of Technology Amenities on Hotel Guest Overall Satisfaction, Journal of Quality Assurance in Hospitality and Tourism,10/2011,12(4),272-288.

11. Clare Jay ,FazuinMohd. Yusoff, (2011). The Role of Guest Amenities in Wellington Hotels, Lincoln University.

12. Abbey R. James, (2008). Hospitality Sales and Marketing, 5th edition, AH\&LA

13. Anton, J. (1996). Customer Relationship Management: Making Hard Decisions with Soft Numbers, Upper Saddle River: Prentice-Hall.

14. Baker, S., Bradley, P. \&Huyton, J. (1998). Principles of hotel front office operations Australian edition (2nd ed.). Melbourne, Australia: Hospitality Press.

15. Bardi, I J. I A. (2007). Hotel Front Office Management (4th ed.). Hoboken, NJ: John Wiley \& Sons, Inc.

16. Boyce, J. (2005). Marketing research (2nd ed.). North Ryde, Australia: McGraw-Hill.

17. Braham, (1988). Hotel front office (1st ed.). London, UK: Hutchinson Education.

18. C.R. Kothari, (2004).Research Methodology ,Methods and Techniques,New Age International (P) Ltd,Publishers 